\title{
Are Cash Balance Pension Plans A Viable Retirement Program For Corporate America?
}

\author{
John J. Lucas, Purdue University Calumet, USA
}

\begin{abstract}
Cash Balance Pension Plans are a defined benefit plan where employees have a hypothetical account that increases annually, as a result of compensation credit as well as interest credit. In essence, cash balance pension plans combine elements of both a traditional defined benefit plan and a defined contribution plan (Lucas, 2007). This paper examines the recent trends and legal ruling regarding cash balance pension plans. The paper also provides an examination of the role of the Pension Protection Act (PPA) of 2006 and its impact on cash balance pension plans. An evaluation will also be presented to determine if cash balance pension plans are a viable retirement program option in corporate America.
\end{abstract}

Keywords: Cash Balance Retirement Programs; Defined Benefit Plan; Defined Contribution Plan

\section{BACKGROUND}

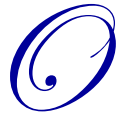

ne of the most popular and common employee benefits offered by corporate America are retirement plans. Some of the common retirement benefits offered include: defined benefit pension plans, cash balance pension plans, 401-k plans, and employee stock ownership plans (ESOP) (Lucas, 2005). One type of retirement plan is cash balance plans which were created in the mid 1980's, and quickly gained popularity across corporate America. In 1985, Bank of America established a cash balance plan and has been credited as the first major employer to adopt the concept of cash balance plans as a viable alternative to the traditional defined benefit pension plans (www.ebri.org).

Cash balance plans were described as a "hybrid plan" with characteristics of both a traditional defined benefit plan and a defined contribution plan. In other words, cash balance plans are referred to as a hybrid plan because, legally, they are defined benefit plans, but also contain features of a defined contribution plan (GAO, 2005). Typically, an employer made a hypothetical contribution to an established individual account. The employees' account was credited each year with a "pay credit" representing a percentage of pay or flat dollar amount and also an "interest credit." (Mincer, 2010). Thus, cash balance plans expressed benefits as a hypothetical individual account balance that is based on both payment credits and interest credits (GAO, 2005). At retirement, the plan provided benefits in the form of a lump-sum distribution or annuity based upon those credits earned by the plan participant. It is interesting to note that these individual accounts were strictly hypothetical, and the pension fund that existed to cover the accounts could be more or less than the total of the accounts (Lucas, 2005). Therefore, the investment risks were borne solely by the employer, as increases or decreases in the value of the plan's investment do not affect the benefit amounts promised to the plan participant (www.dol.gov).

Cash Balance plans were subject to the requirements of the Employee Retirement Income Security Act (ERISA) of 1974 in regard to minimum standards pertaining to eligibility, vesting, and funding (www.ebri.org). Similar to a defined benefit plan, a cash balance plan had no invest risk because the investments of those plans are managed by the employer or an investment agent appointed by the employer (www.dol.gov). Additionally, cash balance plans were usually insured by the Pension Benefit Guaranty Corporation (PBGC), as were defined benefit plans (Lucas, 2005). If a cash balance plan were terminated with insufficient funds, the PBGC has authority to assume control over the plan and pay pension benefits up to the limits set by federal law (www.dol.gov). 
By 1999 , twenty percent of the Fortune 500 companies had converted their traditional pension plan to cash balance plans (Lucas, 2005). However, as cash balance plans were gaining momentum, a major controversy surrounding them surfaced. The conversion to cash balance plans was controversial because of the effect it may have on pension benefits of workers of different ages, as well as of years of service (GAO, 2005). In essence, cash balance plans could be discriminatory toward older, long-term employees (Lucas, 2005). Specifically, the conversion of cash balance sometimes resulted in the so-called "wear-away" situation where older workers needed to earn additional pension benefits in order to attain the previous level of a defined benefit plan (Lucas, 2007). For example, a worker in his or her 60 's, instead of receiving the equivalent of fifty percent of pay each year credited to his or her pension would only receive four percent with a cash balance plan. The net result is that older workers could possibly need to work five or more years to earn their way back to the previous level of benefits of the defined benefit plan (Lucas, 2005).

The controversy of cash balance plans climaxed with the Cooper vs. The IBM Personal Pension Plan (2003) decision. In July 2003, U.S. District Judge G. Patrick Murphy ruled that the cash balance plans implemented at IBM discriminated against older workers (Lucas, 2007). However, the United States Court of Appeals of the Seventh District reversed the judgment of the district court arguing that all the terms of the IBM's plan were ageneutral and every employee with the same salary and service record received similar opening account balances with the new cash balance plans. The $7^{\text {th }}$ District reasoned that the interest credits were not benefit accruals as they simply restored early retirement discounts that would have applied had the benefits started before the age of 55 (www.shrm.org).

In August 2006, President George W. Bush signed into law the Pension Protection Act (PL 109-280). The 907-page federal law consisted of fourteen major Titles ranging from Title 1, Reform of Funding Rules for Single Employer Benefit Pension Plans, to Title XIV, Tariffs Provisions. The Pension Protection Act (PPA) clarified the rules pertaining to cash balance plans. Under Title VII, "Benefit Accrual Standards," there were "special rules relating to age" established for the defined benefit plans, which included cash balance plans. In essence, cash balance plans do not ordinarily discriminate against workers if the benefits were fully vested after three years of service and interest credits were not above the market rate of return (Purcell, 2006). Additionally, the provision included an age discrimination test "comparison to similarly situated younger individual" (Lucas, 2009). This federal law also prohibited the wear-away of accrued benefits, if the conversion to a cash balance plan by an employer occurred after June 29, 2005 (Purcell, 2006).

Although the PPA of 2006 clarified that on the surface cash balance plans do not ordinarily discriminate against older workers, the number of new cash balance plans had stalled because of a lack of regulations by the Treasury. In the Fall 2010, the Treasury Department proposed various regulations in its effort to clarify how cash balance plans were to be managed (Mincer, 2010). On October 19 2010, the U.S. Internal Revenue Service published in the Federal Register "Additional Rules Regarding Hybrid Retirement Plans" outlining these regulations for cash balance plans. One significant regulation was to lower the interest credit rate that employers utilized to determine interest credits on cash balance accounts. This proposed rule was expected to reduce the employer contribution to some existing cash balance plans which could find them even more attractive to employers (Mincer, 2010).

Another proposed regulation by the IRS was the "preservation of capital" rule. This regulation was intended to protect cash balance plan participants in an effort that they could not receive less than the aggregate of all employer contributions at the time of withdrawal (www.shrm.org). Still another major proposed regulation by the IRS was to broaden the investment choices selected by employers for the offered cash balance accounts (Mincer, 2010). It is interesting to note that the IRS initially stated that these proposed rules pertaining to cash balance plans would take effect on January 1, 2012. However, in "Notice 2011-85," issued on October 12, 2011, the IRS stated that the finalized rules would be effective no earlier than January 1, 2013. There was no reason provided by the IRS regarding for the delay in the effective date or even whether the rules would differ from the proposed rules (www.shrm.org).

In summary, cash balance pension plans were referred to as hybrid plans because they had characteristics of both a traditional defined benefit plan as well as a defined contribution plan. One of the first major employers to 
adopt the concept of cash balance plans was Bank of America in 1985. As cash balance plans were gaining popularity in the 1990's, a controversy surfaced that these retirement plans potentially discriminated against older workers. This controversy climaxed with the Cooper vs. The IBM Personal Pension Plan decision. The enactment of the Pension Protection Act (PPA) of 2006 outlined specific guidelines for cash balance plans reinforcing the view that these plans do not ordinarily discriminate against older workers. By the fall 2010, the Treasury Department proposed various regulations in order to clarify how cash balance plans were to be managed by employers. With a history of more than twenty five years in existence, an important question remains whether cash balance plans are truly a viable retirement option for corporate America.

\section{CASH BALANCE PLANS AS A RETIREMENT PLAN OPTION}

Today, cash balance plans have been steadily gaining momentum among small businesses, as well as Fortune 500 companies, as a viable retirement plan option. According to the "2011 National Cash Balance Research Report," by Kravitz Inc., a retirement plan consultant, new cash balance plans have experienced a twenty percent average annual increase for the period of 2001-2009. In comparison, 401(k) plans have only experienced a three percent annual growth rate during this same timeframe (Kravitz, 2011). In 2001, there were approximately 1,337 cash balance plans across the nation, and by 2009 the number grew to 5,480 plans, a 437\% growth increase (Kravitz, 2011). It is also interesting to note that in 2001 cash balance plans made up just $2.9 \%$ of the total defined benefit plans offered and by 2008 they made up 11\% of the total defined benefit plans (Kravitz, 2011).

This spectacular growth experienced by cash balance plans has been primarily with small and mid-size businesses with fewer than one hundred employees. These businesses comprise approximately eighty- two percent of the total cash balance plans across the United States (Kravitz, 2011). In particular, cash balance plans continue to demonstrate rapid growth especially in the health care sector, as medical and dental groups accounted for thirty seven percent of all the cash balance plans that are offered nationally (Kravitz, 2011).

For major companies, with over ten thousand employee participants, there were one hundred and ninety plans, or 3.4\% of the national total of five thousand eight hundred and forty cash balance plans (Kravitz, 2011). Most of these plans were the result of a major employer converting their traditional defined benefit plan to a cash balance plan (Kravitz, 2011). As traditional defined benefit plans continue to be phased out, due to market volatility and costs to maintain them, it is projected that these conversions will increase and the percentage of the nation's total number of cash balance plans of over ten thousand employee participants will also increase.

\section{CONCLUSION}

In retrospect, this paper traced the beginnings and development of cash balance pension plans that gained enormous popularity in corporate America in the 1990's. A controversy pertaining to cash balance plans emerged with the Cooper vs. The IBM Personal Pension Plan court decision. Subsequently, the growth of new cash balance plans in the United States stalled until there was more clarity for employers (Mincer, 2010). In 2006, the Pension Protection Act clarified the rules relating to cash balance plans and reinforcing the view that these retirement plans do not ordinarily discriminate against older workers. However, new cash balance plans were basically on hold because of the lack of regulations by the Treasury as to how these plans were to be managed.

This raises the question of what will the future hold for these cash balance plans as a retirement option for corporate America. Currently, major companies, with over ten thousand employee participants, represent only $3.4 \%$ of the national total of cash balance plans in the United States. The PPA of 2006 did clarify the rules impacting cash balance plans and reinforced the legality of these plans. Perhaps, the proposed IRS regulations, to be effective in 2013, will provide the impetus for a renewed interest and growth of these plans in corporate America and particularly among large corporations. Inasmuch as the legality of these cash balance plans has been addressed and the potential IRS regulations to manage them, it still remains to be seen if cash balance plans will be viewed as an attractive and viable option in the retirement plan landscape in corporate America. 


\section{AUTHOR INFORMATION}

Dr. John J. Lucas is a Professor at Purdue University Calumet and teaches a variety of human resource management courses. He earned his Master of Science in Industrial Relations (MSIR) and Ph.D. degrees from Loyola University Chicago. His research interests are in the areas of labor relations, employee benefits, and health education. He is also a graduate of Purdue University Calumet. E-mail: jlucas@ purduecal.edu

\section{REFERENCES}

1. Cash Balance Pension Plans Questions and Answers, www.dol.gov. Accessed February 6, 2012.

2. Employee Benefit Research Institute. FAQs About Benefits----Retirement Issues. www.ebri.org Accessed October 20, 2011.

3. Lawrence, Stewart D., Is it Time to Reconsider Cash Balance Plans, www.shrm.org. Accessed February 6, 2012.

4. Lucas, John J., The Controversy Surrounding Cash Balance Pension Plans, Journal of the Academy of Business Administration, Vol. 10, No. 1\&2 Spring/Fall 2005.

5. Lucas, John., What is the Future for Defined Benefit Plans in the United States? Journal of Business and Behavioral Sciences, Vol. 15, No 2 Spring 2007.

6. Miller, Stephen, Biggest U.S. Pensions Lost Ground: More Interest in Hybrids. www.shrm.org. Accessed January 25, 2012.

7. Mincer, Julian, Cash Balance Pensions Get Boost, Wall Street Journal, 27 October 2011, Sec C17.

8. National Cash Balance Research Report 2011, www.cashbalancedesign.com. Accessed February 6, 2012.

9. Purcell, Patrick, Summary of the Pension Protection Act. CRS Report for Congress, 23 October 2006.

10. Riggs, Marli D., Cash Balance Plan Numbers Steadily Increasing, www.eba.benefits.com. Accessed February 6, 2012.

11. U.S. General Accounting Office. 2005. Information on Cash Balance Pensions. Washington, D.C. 